\title{
Innovative Magazine Development on Petroleum Materials for Senior High School
}

\author{
Sri Adelila Sari \\ Chemistry Education Department of FMIPA \\ State University of Medan \\ Medan, Indonesia \\ Corresponding: adelila@gmail.com
}

\author{
Tety Darwiyah \\ Chemistry Education Department of FKIP \\ Syiah Kuala University \\ Banda Aceh, Indonesia \\ Email: tety.darwiyah@gmail.com
}

\begin{abstract}
Petroleum is a material contained in the study of chemistry. The materials of petroleum are memorizing and boring as all in the form of theories that require deep understanding. Efforts made to facilitate students in the learning process of chemistry is to create teaching materials that provide a more interesting printed media, such as magazine. This research was aimed to develop an innovative magazine on petroleum materials. The responses of students and teachers to the developed magazine were also studied. The type of study used was research and development. The model of magazine development used in this study was 4-D model. Subjects in this study were two of chemistry teachers and thirty students of class XI MIA-5, at SMAN 7 Banda Aceh. The sampling technique was done by purposive sampling. Data were collected using questionnaire for magazine feasibility, as well as for student and teacher responses. The magazine's feasibility assessment was conducted with several aspects such as media format, visualization, function and clarity in concept of presentation. It has been found that the percentage of eligibility of developed magazine was of 91.67 percent. This percentage value was categorized as very feasible and could be tested to students. In addition, the responses of students and teachers to the developed magazine were found to be 90.33 and 90.00 percent, respectively, with an excellent response category. This study concluded that the innovative magazine on petroleum could be developed and level of feasibility of the magazine as a medium of learning was very feasible.
\end{abstract}

\section{Keywords —development, innovative magazine, petroleum}

\section{INTRODUCTION}

Chemistry is the study of matter, substances and elements involved in its transformation. During this time, students often assume that learning chemistry is not easy. This is because the chemistry covers a very wide and abstract material. Petroleum is a material contained in the study of chemistry and this material is closely related to everyday life. Characteristics of petroleum materials include material that is memorizing and boring, because all in the form of theory that requires a deep understanding that makes students difficulty in remembering the concept if the presentation of the material using the lecture method. Learning will be very tedious if the presentation of the material using lecture methods. Efforts made to facilitate students in the process of learning chemistry is to create a learning media that provides a more interesting picture to read and can increase student learning interest [1]. The proper use of media can also help a learning process in accordance with the purpose of the material. Printed media is a type of media that can be used in learning. This is a media that end product in the form of prints, for example textbooks, magazines, brochures, bulletins and others [2].

Based on the result of interview of students in senior high school SMA Negeri 7 Banda Aceh on learning petroleum material was known that the learning media only use textbooks. Therefore, hopefully by using the developed learning media, it can create a fun learning atmosphere for learners on the material of petroleum. It aims to attract learners' learning interests and enable students to follow chemistry learning either in groups or independently. There are several media that can be used for theoretical chemicals such as petroleum, one of which is the magazine. Magazines also belong to text-based print media. It is still in demand because it is more practical, easy to carry anywhere without the need for help other devices to use it.

A magazine is a periodical issue containing a variety of articles with varied themes. Magazines are usually published weekly, two weeks or monthly. Articles in magazines generally use language styles that are easy for many to understand [3]. Furthermore, magazines are mass media of communication in the form of print that no doubt role and influence on the readers and included in the two dimensional learning media [4].

Based on this background, the development of magazine media was expected to create a fun learning atmosphere for learners on the material of petroleum. It has been argued that there were several advantages of the magazine, i.e., (a) target public, magazines could reach certain segments that were specialized. Long life span, had a longer circulation age; (b) visual quality, more attractive because paper or print quality, especially the news; and (c) sales promotion, as an effective medium for broadcasting advertising messages, tended to promote sales, such as coupons, clue cards. Besides having the advantages of magazines also have shortcomings. The weakness of the magazine were: (a) high cost, because in general using good quality paper and limited copies, this causes higher production 
costs; and (b) distribution, many magazines whose circulation was slow, so it only accumulates in stores. This happens if a magazine do not have an appropriate distribution network. Especially for inland areas, prices could be expensive because of high shipping costs [5].

Some researches related to student and teacher responses to magazine also have been studied. It has been found that the data of chemistry magazine were assessed by colleagues, material experts and chemistry teachers on three aspects. It covered the aspects of material feasibility, feasibility of presentation and the feasibility of language and image. The research found that the magazine to be feasible to use in the learning process of chemistry [6].

The other study found that the development of an electronic magazine was generally successful. Broadly speaking, validators and students commented that the developed electronic magazine has been good. In addition, this was also supported by a hundred percent completeness of students during small group trials and large group trials [7]. Furthermore, the magazine was very interested. The results of questionnaire responses of students obtained a percentage of 85.75 . While the result of teacher response analysis got percentage up to 92.50 . This indicated that the level of science magazine was excellent legibility. In the large-scale test with the respondents of 6 teachers, and 36 students, the questionnaire consisted of 11 questions obtained percentage in a row at 87.5 and 83.44 percent, respectively [8].

Based on the background, the problem formulations in this research were: (a) how was the development of magazine media on chemistry learning of petroleum?, (b) how was the feasibility of magazine media on the learning of petroleum?, and (c) how were the students and teachers of class XI MIA-5 at SMAN 7 Banda Aceh responded to the developed magazine on learning chemistry of petroleum materials?

In addition, the purposes of this research were to: (a) develop a magazine on learning chemistry of petroleum materials, (b) describe the feasibility of magazine media on learning chemistry of petroleum materials, and (c) describe the students' responses of class XI MIA-5 at SMAN 7 Banda Aceh and chemistry teachers' responses to the developed magazine on petroleum material. Furthermore, the benefits of this research were: (a) generating students' motivation in learning chemistry, (b) giving creative ideas for teachers in choosing appropriate media in generating student motivation, and (c) adding insight and knowledge about learning media in order to improve the quality of education, especially chemistry.

\section{METhODOLOGY}

\section{A. Research Type, Approach, and Samples}

The type of research was Research and Development $(R \& D)$. The development model used was a 4-D model. The 4-D research model was a research model used to validate the products used in education and learning. Model 4-D consisted of four stages: Define, Design, Develop and Disseminate
[9]. The approach of this study was qualitative \& descriptive. This study focused on assessing magazine's feasibility and responses of teachers and students of grade XI MIA-5 SMA Negeri 7 Banda Aceh to the developed magazine.

\section{B. Development Procedures of Magazine}

\section{Define phase (definition)}

The purpose of this stage was to determine and define the learning conditions in advance with the objective analysis of the limitations of material developed by magazine. This stage included 5 basic steps, namely: (a) analysis of the front end, which aimed to generate and define the basic problems faced in chemistry learning. Based on this issue, an alternative magazine was devised. In doing the analysis, the front end was needed to consider several things as an alternative development of learning tools, learning theories, challenges, and future demands. Analysis of the front end began with the knowledge, skills, and attitudes that students had to achieve the ultimate goal of the listed goals in the curriculum. The gap between the things that were already known to the students with what was supposed to be achieved by students. Then it was moderation needed would be material as the cover that gap; (b) analysis of students, at this stage the characteristics of learners were studied, such as ability, motivation to learn, background experience, and so forth; (c) analysis of concepts, making the steps that would be done rationally; and (d) formulation of learning objectives.

\section{Design Phase}

The purpose of this stage was to prepare prototype of learning devices. This phase consisted of four steps, i.e., (a) the preparation of a benchmark reference test, the first step that connected between the define phase and design. The test was based on the results of the formulation of specific learning objectives. This test was a tool to measure the change of behavior in students after teaching and learning activities; (b) selection of appropriate media objectives, to deliver learning materials; and (c) format selection. In the selection of this format for example could be done by reviewing the format of existing magazines and have been developed in other countries more advanced.

\section{Development Phase}

The purpose of this phase was to produce a revised learning tool based on input from experts. This stage included: (a) magazine validation by experts followed by revisions, (b) simulations, which were activities of operationalizing lesson plans, and (c) limited trials with actual students. The results of stages (b) and (c) were used as the basis of the revision. The next step was to test further with the number of students who fit the actual class. The study was limited only to the stage of development, disseminate stage was not implemented due to consider the time and cost. Tools and materials used to design 
a magazine were computer supported by Adobe Program InDesign CS6 as well as Corel Draw and a camera. Before magazine development was done, the format was chosen firstly. The media format used three columns because the used paragraph contains short paragraphs. Then the pictures were given to look more interested and could be increased student learning interest.

\section{Data Collection Technique}

Data of students and teachers responses were collected by structured questionnaires that contain questions and space for answers. In addition, the validation sheet was used to get the magazine's validity. All the instruments used were also validated, so that the data obtained was also valid. The feasibility assessment sheet was conducted by three validators, i.e., two lecturers of chemistry education and one chemistry lecturer of Syiah Kuala University. Questionnaire results were obtained from the validator, then the value of the average percentage were calculated.

\section{Student and Teacher Responses}

There were two kind of questionnaire sheets, i.e., for students and teachers. The questionnaire sheet was an instrument that contains some questions that are used to determine the feasibility of developed magazine. This instrument was used to obtain responses of students and teachers to developed magazine. In addition, to analyze the data obtained from the questionnaire, the frequency distribution formula was used.

\section{RESULTS AND DISCUSSION}

\section{A. Development of Magazine on Petroleum Material}

The magazine was developed using steps which started from define, design and development.

\section{Define}

At this stage, the determination and definition of learning requirements were made. There were several things to be done, i.e., (a) Analysis of the front end, was an analysis of problems faced by students in implementing the learning process. This stage was done to see the students' learning motivation in achieving the goals of learning. Based on the results of interviews of researchers with students in SMA Negeri 7 Banda Aceh obtained some information that chemistry learning on petroleum materials only used textbook and have never used magazines. However, for other materials the teacher used media and learning models.

Based on the interview results, the researcher was interested to develop a learning media that was in the form of magazine. Magazine was expected to help students and teachers in the learning process, so that the learning process became more active and creative. The learning process was using magazine could be used as an alternative to eliminate the saturation level of students and could increase student learning interest. If the student's interest in learning has increased although little, but it has a great influence on student learning outcomes obtained. It has been argued that the learning process undertaken by learners should be supported by interesting learning resources and in accordance with the interests of learners. This learning resource in the form of magazine that the contents of the material in accordance with the standard content, so that with this magazine, learners could be helped to learn and get meaningful about chemistry subjects being studied [6]. Further, as a magazine learning media could supported students' understanding of the material presented by the teacher and provided an interesting nuance of learning [8].

(b) Student analysis, was a stage to see the characteristics of learners. The purpose of this analysis was to determine the ability and motivation of student learning both in groups and individually. Research subjects were class XI MIA-5. It was chosen because the students 'learning interest was still lacking. Besides that, it was needed to motivate and attract learners' learning interests. The magazine was media that could be used as a tool to understand the material, as well as to provide pleasure in learning. As an independent source of learning, magazine was expected to support students' understanding of the material presented by teachers and provide an interesting learning nuance [4]. Magazine was one of the media that contains information about the development of science and technology. Advantages of a magazine that was displayed varying text with the images combined with attractive colors, so as to attract the interest of many people to read it [10].

(c) Concept analysis, was the stage to know basic competence (BC), learning objectives and limitations of material to be taught. Before $\mathrm{BC}$, learning objectives, and limitations of the material were determined, also the syllabus on petroleum material was prepared. The choice of petroleum material because this material was rote, boring and difficult to understand because all in the form of theory. So that, this material required a deep understanding. This was in line with the statement that earning difficulties were a condition experienced by students who were characterized by certain obstacles that lead to the achievement of learning objectives [11]. The basic material of petroleum was found in BC 3.2, which was understanding the process of formation and technique of separation of petroleum fractions and their usefulness. In addition, BC 4.2, which presented the result of understanding about the formation process and technique of separation of petroleum fractions and their usefulness. BC could be translated into several indicators, i.e., explaining the meaning of petroleum, petroleum composition, petroleum processing, and the impact of petroleum combustion. The material was presented in relation to everyday life. The learning objectives would be determined based on learning indicators developed in accordance with core competencies. 
(d) Analysis of learning objectives. Learning objectives could be formulated based on concept analysis that has been developed in accordance with indicators of BC 3.2 and $\mathrm{BC}$ 4.2. The purpose of learning was that students were able to explain the definition of petroleum, petroleum composition, petroleum processing, and the impact of petroleum combustion.

\section{$\underline{\text { Design }}$}

This stage was the step of made the design. In this stage, the product of petroleum magazine would be produced. Petroleum material was one of the high school (SMA) chemistry teaching materials for class XI at Semester 1 . The tools used in the process of designing the magazine were adobe InDesign software and Corel draw software, and images related to petroleum. The components to be considered in magazine design were determined, such as the number of magazine pages, formatting, attractiveness, font size and the use of blank spaces and described as follows:

(a) Determine the number of pages in a magazine. The number of pages was set in a way divided into multiples of 4 , this was due to avoid the advantages or disadvantages of several blank pages. The magazine that has been designed was 16 pages.

(b) Format. The margin format used should be consistent from page to page. Magazines that has been designed using the format margin left, right, top and bottom was $1.5 \mathrm{~cm}$. The designed magazines also used a 3 column format, because for articles that used short paragraphs 3 column format more appropriate. The selection of 3 column format should be adjusted with the articles contained in the magazine.

(c) The attraction. To attract reading interest of students in magazines, every page related to the subtitle of petroleum material was added to the images related to the material and colored on the background display.

(d) Font size. Magazine that has been designed used font size 10 point, the design of the magazine should avoid the use of letters with small size for example under 7 points because it could affected the process of sharpness of the printer. Fonts on magazines, such as Time New Roman, Arial, Georgia Newsgoth BT and others could be used and customized. In this magazine, the Newsgoth BT font was used. Font Newsgoth BT was the most commonly used writing on article writing in magazines.

(e) Use of blank spaces. In order for no blank spaces in the magazine, so that it was needed to add some images related to petroleum material on the designed magazine. The components were considered in magazine design can be seen in Table 1.

\section{$\underline{\text { Development }}$}

This stage was an advanced stage of designing. The purpose of this stage was to produce a draft of instructional media. The magazine has been revised based on input from experts' validators. The data obtained from the trials and the results of the questionnaire responses of students and teacher responses. Fig. 1 shows some pages of developed magazine on petroleum material.

TABLE I. CONSIDERATIONS OF COMPONENTS IN MAGAZINE DESIGN

\begin{tabular}{|c|c|c|}
\hline No. & Component & Explanation \\
\hline \multirow[t]{4}{*}{1} & \multirow[t]{4}{*}{ Pages } & $\begin{array}{l}\text { The number of pages were arranged into } \\
\text { multiples of } 4 \text {. }\end{array}$ \\
\hline & & $\begin{array}{l}\text { The magazine that has been designed amounted } \\
\text { to } 16 \text { pages. }\end{array}$ \\
\hline & & $\begin{array}{l}\text { Format magazine margin should be consistent } \\
\text { from page to page. }\end{array}$ \\
\hline & & $\begin{array}{l}\text { The design of magazine used the } \\
\text { format margins left, right, top and bottom } 1.5 \\
\mathrm{~cm} \text {. }\end{array}$ \\
\hline 2 & Format & $\begin{array}{l}\text { Magazine that has been designed using } 3 \text { column } \\
\text { format. }\end{array}$ \\
\hline \multirow[t]{3}{*}{3} & \multirow[t]{3}{*}{ Attractiveness } & $\begin{array}{l}\text { To attract readers of the magazine, it was added } \\
\text { the pictures related to petroleum materials and by } \\
\text { the color of the background. }\end{array}$ \\
\hline & & It has been designed using 10 -point font size. \\
\hline & & $\begin{array}{l}\text { Avoid the use of letters with the small size, } \\
\text { example below } 7 \text { points because it could } \\
\text { affected the sharpness of the printer. }\end{array}$ \\
\hline 4 & Font size & $\begin{array}{l}\text { The use of letters in magazine design should be } \\
\text { adjusted. }\end{array}$ \\
\hline
\end{tabular}

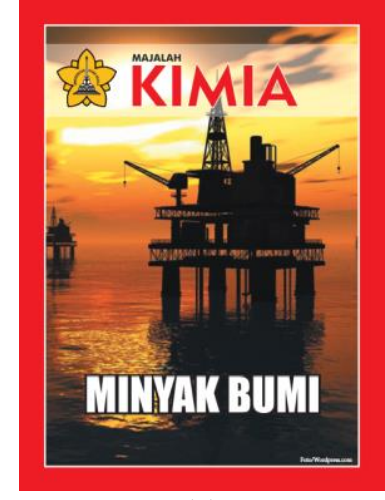

(a)

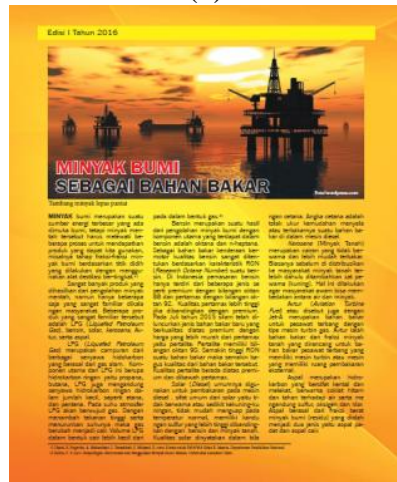

(c)

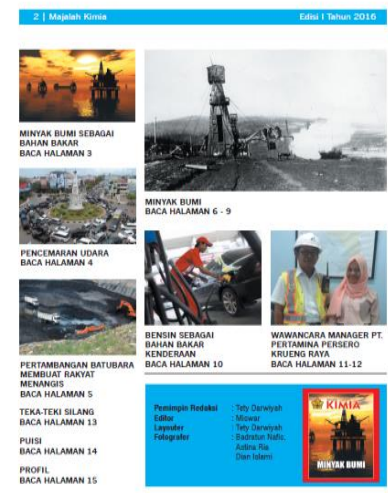

(b)

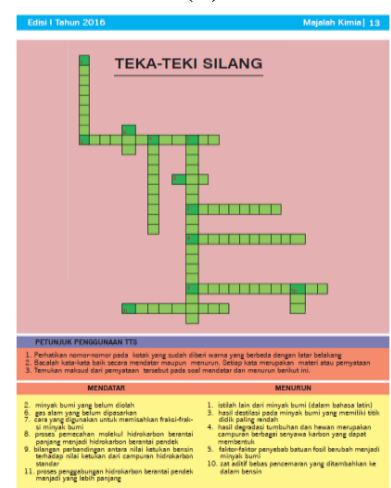

(d)
Figure. 1. Magazine development: (a) cover, (b) table of content, (c) page 3 , and (d) page 13 
The process of developing magazine content was included the collection of data and article writing on every rubric as well as look for images from various sources to support the contents of the articles to be loaded. Overall, design of the layout and the selection of images/pictures on every sub heading in the thematic material depended on the contents of the writing in the magazine. After all the needed information were collected, then the information would be compiled to the layout of the article in a balanced and sustainable. So that, it look as a whole dynamic and comfortable for viewing. This process was called the stage of laying out. The completed magazine layout would undergo a revision phase based on feedback from the expert validators, then the magazine would be printed.

\section{Magazine Validation}

Magazine was produced from the final stages of development, then tested the feasibility to see if the magazine was worthy tested to students. The feasibility test covered several aspects: magazine format, visual, functionality and magazine clarity in concept presentation. The experimental results of each aspect were found to be $83.33 ; 86.90 ; 83.33$; and 89.58 percent respectively, while the average of eligibility percentage for all aspect was up to 91.67 percent. Based on the results of the magazine was valid and worthy of trial.

It was in accordance with research has been conducted previously, that teaching materials based on Smart Student Magazine in science lesson in junior high school (main subject: motion on objects) included in the category quite valid with an average value of 3.99. This assessment was the average of the assessment of four aspects, i.e., aspects of the format with a value of 4; language aspect with value 4; aspect of content with 4.08 value; and aspect of illustration with value 3.89. This was because the highest score on the content aspect was up to 4.08 , so it was quite feasible to be used in learning activities [10].

\section{(a) Limited Test}

A limited test was conducted to 30 students of SMA Negeri 7 Banda Aceh. Students were divided into 7 groups consisted of 4 groups and 2 groups of 5 people. Figure 2 shows the read activities of magazine in the class.
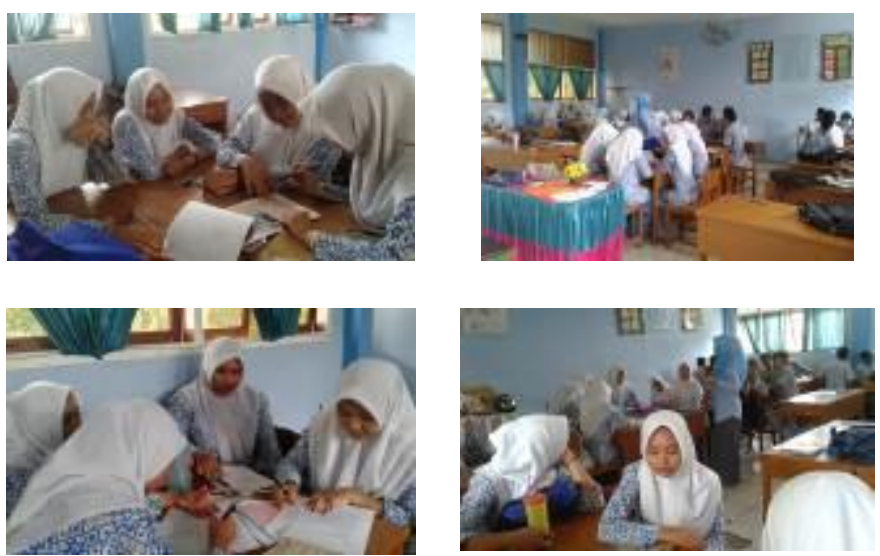

Figure 2. Students used magazines for study on petroleum

\section{(b) Responses of Students and Teachers to Petroleum Magazine}

Before the magazine was distributed to the students, the researcher first explained about the developed magazine. After that, magazines were distributed to each group and the students were given 60 minutes to read the magazines in turn. Magazine trials were conducted on students those who have studied petroleum material before. From the magazine, at least students found new learning related to petroleum.

Student's response to magazine development has been measured by calculation of questionnaire results given to student which were consisted of 10 questions. Before students gave their response, the researcher first explained the purpose of his research. After that, students were asked to read and understand the contents of magazine. After finished in observe the magazine, the questionnaire sheets were distributed. The student's response was also aimed to know the advantages and disadvantages of the magazine that has been developed.

Based on the test of 30 students, the results showed that 90.33 percent of students' responses with very good category. According to the developed magazine, students were interest in learning due to a view colored background and has images/photos associated with the material. In addition, it also due to the language that was easily to be understood.

This was in accordance with the previous study results that based on questionnaires given to learners after the learning process. It has been found that as many as 97 percent of students said the learning took place quite well, as much as 80 percent of students learners learn magazine chemistry quite complete. Besides that, as much as 37 percent of students stated strongly agree that the chemistry magazine was able to facilitate in learning chemistry [6]. The results of the questionnaire of student responses to the magazine has been developed in first trial with the number of students 10 and 2nd trials with the number of 34 students were 92.30 and 85.15 percent, respectively with good category [8].

The teachers' responses to magazine development on petroleum material could be known through a questionnaire which contained 8 questions. Based on the results, responses of teachers could be earned an average of 90 percent. This was indicated that the magazine was developed very well. Judging from the results of teachers' responses could be seen that the use of magazines could helped teaching and learning process on petroleum materials. This was in accordance with the previous study that on the large-scale test with respondents' of six, questionnaires for teachers were consisted of 11 questions, obtained percentage of 83.44 percent [7]. It showed the magazine was very interesting. Furthermore, one research suggested that the results of feasibility observation green magazine assessed by teachers in the study with a percentage of 76.92 percent, this was indicated that the magazine media both used as a learning resource [8]. 


\section{CONCLUSIONS \& SUGGESTIONS} as follows:

Based on the results, some conclusions can be drawn

1. Magazine as a medium of learning was developed through several systematic phases, i.e., define, design, and development.

2. The result of the feasibility test of magazine was obtained 91.67 percent, categorized as well, so that the magazine could be tested to the students.

3. Students and teachers responses to the development of the petroleum material magazine could be categorized as "very good" with an average percentage of 90.50 and 90.00 percent, respectively.

Some suggestions can be given as follows:

1. The magazine can be used as an alternative media on chemistry learning.

2. The disseminate stage can be studied using this developed magazine.

3. Teachers should always attempt to use different learning media so that during the learning process can interest students to learn.

\section{REFERENCES}

[1] Fajri, L, Martini, K. S and Nugroho, A. "Improving Learning Materials Colloid Chemistry Through Cooperative Learning TGT (Team Games Tournament) Equipped with Crossword Puzzles for Students Grade XI IPA 4 SMAN 2 Boyolali Even Semester of the Academic Year 2011/2012". J of Chemistry Education (JPK), Vol. 1 No. 1 . 2012. ISSN 2337-9995
[2] Setyono, Y. A, Sukarmin, and Wahyuningsih, D. "Development of Learning Media in the form of Bulletin in Pocket Book Form for Physics Learning Class VIII Meteri Gaya Viewed from Student Interest". J of Physics Education, Vol. 1 No. 1. 2013.

[3] Enterprise, J. "88 Ways Hunting Inspirational Ideas for Blog”. Jakarta: PT Elex Media Komputindo. 2010.

[4] Nurjanah, J. R, Sukarmin, Rahardjo, D. T. "Pengembangan Media Pembelajaran Interaksif E-Magazine pada Materi Pokok Rotasi untuk SMA Kelas XI". Jurnal Materi dan Pembelajaran Fisika (JMPF), Vol 4 No 1. 2014.

[5] Rumanti, MA. "Fundamentals of Public Relations Theory and Practice". 2002. Jakarta: PT Grasindo.

[6] Yulianto, E and Rohaeti, E. "Development of Chemical Magazine for Improving Motivation of Learning and Creativity of Class X Students of SMA N 1 Mlati”. J of Science Education, University of Muhammadiyah. 2013.

[7] Asfuriyah, S and Nuswowati, M. "Development of Science magazine Contextual Learning Based on Global Warming Scene to Improve Student Learning Interests". J of Science Education Journal Unnes 4: 1. 2015.

[8] Dewi, N. A dan Warso, A. W. D. D. "Pengembangan Majalah Green Sebagai Media Pembelajaran Biologi pada Materi Sistem Reproduksi Manusia untuk Siswa Kelas XI IPA SMA”. Jurnal JUPEMASI-PBIO, Vol 1, No 1. 2014.

[9] Susanti, D, Soetadi, W. Surantoro. "Formulation of Classical Physics Diagnostic Test of Class XI Class on Material of Business and Energy”. J of Physics Education, Vol. 2 No. 2. 2014.

[10] Rangsing, B, Subiki and Handayani, RD. "Development of PhysicsBased Physics Teaching Materials of Smart Student Students (MBPF) on Science Lesson in Junior High School (Main Subject of Motion on Objects)". Learning Journal of Physics, Vol. 4 No. 3. 2015.

[11] Ristiyani, E dan Bahriah, E. S. "Analisis Kesulitan Belajar Kimia Siswa Di SMAN X Kota Tangerang Selatan”. Jurnal Penelitian dan Pembelajaran IPA, Vol 2 No 1. 2016. 